\title{
Surto de febre amarela em bugios
}

\author{
Outbreak of yellow fever in brown howlers \\ Eliza Simone Viégas Sallis ${ }^{1}$, Shana Letícia Garmatz ${ }^{1}$, Rafael Almeida Fighera ${ }^{1}$, \\ Vera Lúcia Reis Souza de Barros² \& Dominguita Lühers Graça ${ }^{1}$

\section{RESUMO}

A febre amarela é uma infecção aguda causada por um Flavivirus (VFA) transmitido por mosquitos, endemica nas regiões tropicais da América do Sul. O objetivo desta nota prévia é relatar a ocorrência de um surto da doença no Sul do Brasil. Durante os meses de outono de 2001, um surto de doença em bugios vitimou aproximadamente oitenta exemplares da espécie Alouatta fusca numa floresta no Oeste do Rio Grande do Sul (Santo Antônio das Missões e Garruchos). Os habitantes do lugar relataram que os animais caiam das árvores gravemente enfermos ou mortos. Os populares observaram que os animais tinham amarelamento acentuado da pele e mucosas visíveis. O cadáver de um dos bugios encontrados mortos foi necropsiado no Laboratório de Patologia Veterinária do Hospital Veterinário da Universidade Federal de Santa Maria. $\mathrm{O}$ animal era uma fêmea em mau estado corporal e as lesões observadas na necropsia consistiam em icterícia acentuada de mucosas, grandes vasos e órgãos internos. A bexiga continha urina amarelada com flocos esbranquiçados. Tecidos de vários órgãos foram incluídos em parafina e corados pela hematoxilina e eosina. Foi detectada necrose de coagulação massiva do fígado com degeneração gordurosa dos hepatócitos remanescentes, degeneração do epitélio tubular renal com cilindros hialinos na luz tubular, e necrose variável dos folículos linfóides do baço. As lesões foram sugestivas de febre amarela. Foi realizada imunoistoquímica de cortes histológicos de fígado e rim para detecção de antígenos do vírus da febre amarela (VFA). Foi usado um anticorpo policlonal de camundongo (diluição 1:1600) e um complexo comercial estreptadividina-fosfatase alcalina que reagiu com a biotina ligada ao anticorpo secundário. O teste foi positivo para antígenos do VFA e o diagnóstico de febre amarela em primatas foi formulado pela primeira vez no Estado do Rio Grande do Sul.

Descritores: febre amarela, VFA, bugios, imunoistoquímica.

\begin{abstract}
Yellow fever is an acute mosquito-borne flavivirus (YFV) infection which presents with fever, icterus, albuminuria and hemorrhage. It is herein reported an outbreak of the disease in Southern Brazil. During fall 2001, an outbreak of a disease in brown howlers that killed about eigthy monkies was reported in a subtropical forest in Southern Brazil. The neighbors reported that the monkeys dropped from the trees very ill or already dead. They observed that the animals had deeply yellow skin and mucosae. One of the monkies was necropsied at the Veterinary Hospital of the Universidade Federal de Santa Maria. Gross lesions included intense yellow discoloration of skin, mucosae and internal organs. Paraffin-embedded tissues stained with Hematoxylin-eosin evidenced massive coagulation necrosis of hepatocytes, tubular degeneration and hyaline intratubular casts in the kidneys and variable degrees of necrosis of the follicular nodes of the spleen. The history, gross lesions and histological features were considered suggestive of yellow fever and immunohistochemistry on sections of liver and kidney was performed. A mouse polyclonal antibody (dilution 1:1600) was used for YFV antigen detection and a commercially available Streptavidin-alkaline phosphatase complex, that reacted with the biotin linked with the secondary antibody. The slides were counterstained with Mayer's hematoxylin and mounted in Entellan. Positive and negative controls were run with every test. Cells stained positive for YFV. The diagnosis of yellow fever in primates was done for the first time in the region.
\end{abstract}

Key words: yellow fever, YFV, brown howlers, immunohistochemistry.

'Setor de Patologia Veterinária, Departamento de Patologia, Universidade Federal de Santa Maria (UFSM), 97105-900 Santa Maria, Brasil. ${ }^{2}$ Instituto Evandro Chagas, Belém do Pará, Brasil. CORRESPONDÊNCIA: D. L. Graça [dlgraca@lince.hcv.ufsm.br]. 


\section{INTRODUÇÃO}

A febre amarela é uma doença viral, endémica nas regiões tropicais da América do Sul e da África [4]. O VFA é um Flavivírus (Togaviridae) que causa infecção aguda com febre, icterícia, albuminúria e hemorragia. Os vetores artrópodes são mosquitos dos gêneros Aedes (aegypti e albopictus) e Haemagogus. A zoonose é endémica apesar da existência de uma vacina eficaz $[1,2]$. Atualmente, a infecção pelo VFA pode ser confundida com doenças hemorrágicas semelhantes [1-3] que se sobrepõem geograficamente em algumas regiões da América do Sul. A distinção clínica entre as doenças pode ser difícil, por isso é necessário realizar métodos específicos como o imunoistoquímico para a confirmação de qualquer um dos diagnósticos [2].

\section{MATERIAIS E MÉTODOS}

Um dos bugios recolhidos pela Vigilância Sanitária da região, foi necropsiado no Laboratório de
Patologia Veterinária da Universidade Federal de Santa Maria. Foi observada icterícia acentuada de tecidos e plasma, e urina amarelada com flocos esbranquiçados. Tecidos de vários órgãos foram incluídos em parafina e corados pelo H\&E. As lesões consistiam em necrose massiva do fígado com hepatócitos remanescentes vacuolizados, degeneração tubular renal com cilindros hialinos intra-tubulares e necrose dos folículos linfóides do baço. Os dados clínicos, a macroscopia e as lesões histológicas foram altamente sugestivas de febre amarela (Figura 1), e foi realizada imunoistoquímica em cortes de fígado e rim, para visualização da presença do vírus, no Instituto Evandro Chagas, Belém, Pará. Foram usados um anticorpo policlonal de camundongo na diluição 1:1600, e um complexo comercial de Estreptavidina-fosfatase alcalina que reagiu com a biotina ligada ao anticorpo secundário. Os cortes foram contra-corados com Hematoxilina de Mayer e montados em Entellan. Foram feitos controles positivos e negativos para cada teste.

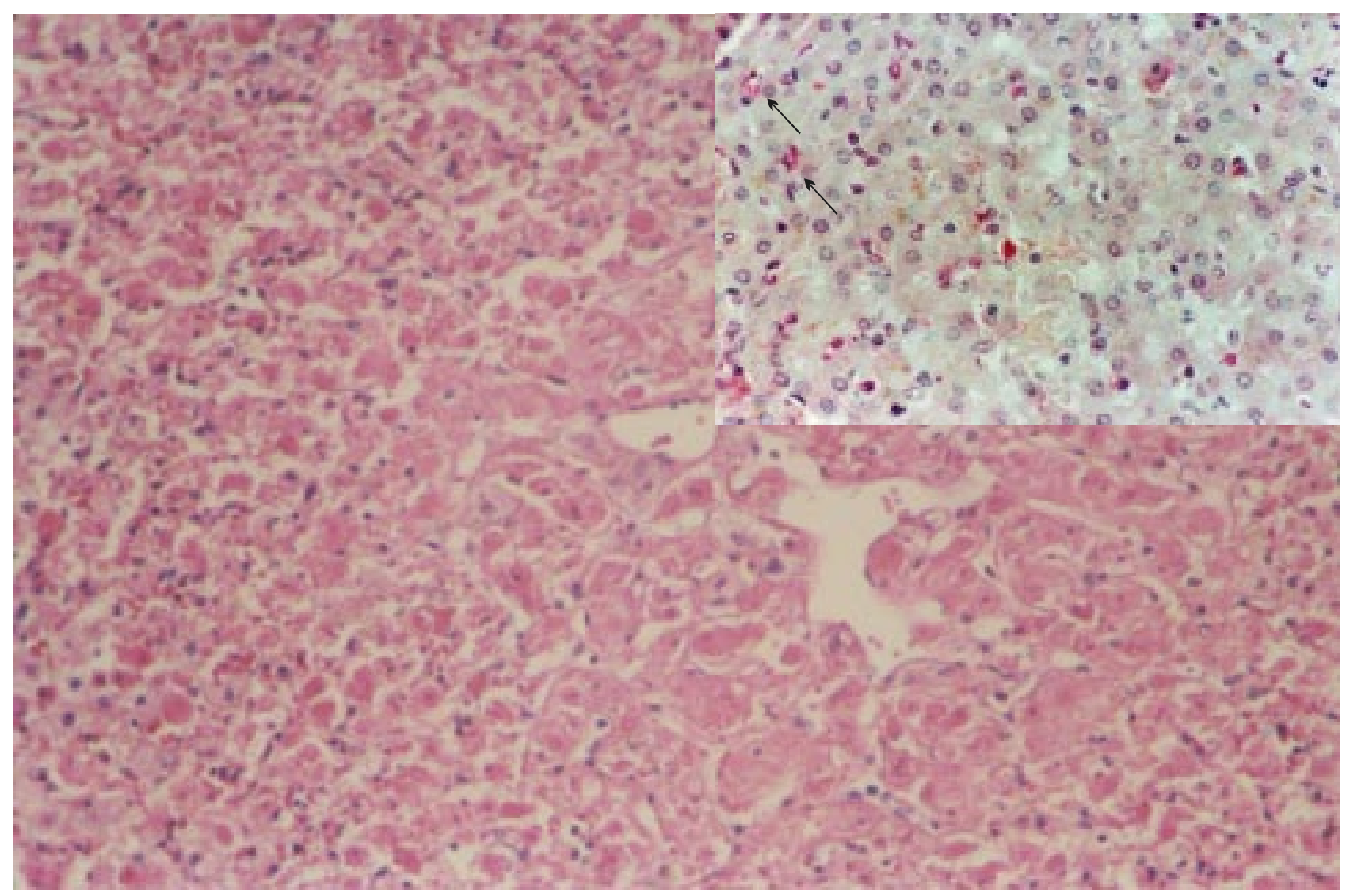

Figura 1. Fígado de bugio com extensa necrose de hepatócitos. H\&E. Objetiva 10. Detalhe: Hepatócitos positivos (setas) ao YFV. IHQ, fosfatase alcalina, substrato vermelho, hematoxilina de Mayer. Objetiva 40. 


\section{RESULTADOS}

O YFV foi detectado nas células tubulares renais e em hepatócitos (Figura 1 - detalhe). Houve, portanto, confirmação do diagnóstico de febre amarela.

\section{DISCUSSÃO E CONCLUSÕES}

A confirmação imunoistoquímica da doença foi necessária já que a febre amarela e a dengue, além de serem transmitidas pelo mesmo vetor artrópode, se sobrepõem em regiões do Brasil. Além disso, o diagnóstico diferencial entre as doenças não é clínico e sim histológico.
No Brasil, a febre amarela urbana foi controlada nos últimos 50 anos através do controle do Aedes sp [5]. Ultimamente, esse controle foi negligenciado e a dengue aumentou no sudeste do país enquanto a febre amarela ocorreu em cidades do Rio Grande do Sul, provavelmente acompanhando o destruição das florestas e a migração do vetor.

As medidas sanitárias incluem o controle do mosquito e a vacinação das populações humanas em risco. Após o diagnóstico de febre amarela nos bugios, os habitantes de localidades adjacentes à floresta foram vacinados [6].

\section{REFERÊNCIAS}

1 De Brito T., Siqueira S.A.C., Santos R.T.M., Nassar E.S., Coimbra T.L.M. \& Alves V.A.F. 1992. Immunohistochemical detection of viral antigens in the liver, kidney and heart. Pathology Research Practice. 188: 177-181.

2 Hall W.C., Crowell T.P., Watts D.M., Barros V.L.R., Kruger H., Pinheiro F. \& Peters C.J. 1991. Demonstration of yellow fever and dengue antigens in formalin-fixed paraffin-embedded human liver by immunohistochemical analysis. American Journal of Tropical Medicine and Hygiene. 45: 408-417.

3 Monath TP. 1985. Flaviviruses. In: Fields B.N. (Ed). Virology. New York: Raven Press, pp. 955-1004.

4 Monath TP. 1998. Yellow fever. In: Palmer SR, Soulsby L \& Simpson DIH (Eds). Zoonoses. Oxford: University Press, pp. 487-498.

5 Mondet B., Rosa A.P.A.T. \& Vasconcelos P.F.C. 1996. Les risques d'épidémisation urbaine de la fièvre jaune ao Brésil par les vecteurs de la dengue. Bulletin de la Société de Pathologie Exotique. 89: 107-114.

6 Sallis E.S.V., Graça D.L., Garmatz, S.L., Fighera R.A. \& Barros V.L.S. 2002. Fiebre amarilla em primates (Alouatta fusca) en el sur de Brasil. Descripción de un caso. In: $18^{\circ}$ Congreso Panamericano de Ciencias Veterinarias (Havana, Cuba). Resumo em meio digital. 